\title{
Karakteristik limbah dan dampaknya bagi kesehatan pembatik di Lendah, Kulon Progo
}

\author{
Suhartini, ${ }^{1,}$ Sri Awalia Febriana, ${ }^{2}$ Ida Bagus Gede Surya Putra Pidada, ${ }^{1}$ Hendro Widagdo, ${ }^{1}$ Martiana \\ Suciningtyas, ${ }^{1}$ Yudha Nurhantari, ${ }^{1}$ Dewanto Yusuf Priyambodo, ${ }^{1}$ Agus Surono, ${ }^{3}$ Roto, ${ }^{4}$ Geraldine Nadita \\ Putri Kinasih, ${ }^{5}$ Pramudji Hastuti, ${ }^{5}$ dan Sri Sutarni ${ }^{6}$ \\ ${ }^{1}$ Departemen Ilmu Kedokteran Forensik dan Medikolegal, Fakultas Kedokteran, Kesehatan Masyarakat, \\ dan Keperawatan, Universitas Gadjah Mada, Yogyakarta, Indonesia \\ ${ }^{2}$ Departemen Dermatologi dan Venereologi, Fakultas Kedokteran, Kesehatan Masyarakat, dan \\ Keperawatan, Universitas Gadjah Mada, Yogyakarta, Indonesia \\ ${ }^{3}$ Departemen Ilmu Kesehatan THT-KL, Fakultas Kedokteran, Kesehatan Masyarakat, dan Keperawatan, \\ Universitas Gadjah Mada, Yogyakarta, Indonesia \\ ${ }^{4}$ Departemen Kimia, Fakultas Matematika dan Ilmu Pengetahuan Alam, Universitas Gadjah Mada, \\ Yogyakarta, Indonesia \\ ${ }^{5}$ Departemen Biokimia, Fakultas Kedokteran, Kesehatan Masyarakat, dan Keperawatan, Universitas \\ Gadjah Mada, Yogyakarta, Indonesia \\ ${ }^{6}$ Departemen Ilmu Penyakit Saraf, Fakultas Kedokteran, Kesehatan Masyarakat, dan Keperawatan, \\ Universitas Gadjah Mada, Yogyakarta, Indonesia
}

\section{Submitted: 29 Desember 2018 Revised: 31 Januari 2019 Accepted: 18 Maret 2019}

ABSTRAK Cat sintetis pewarna batik sering mengandung logam berat misalnya timbal $(\mathrm{Pb}), \mathrm{krom}(\mathrm{Cr})$, silika (Si), dan $\mathrm{HCl}$ atau ion klorida $\left(\mathrm{Cl}^{-}\right)$. Pemakaian logam berat jangka lama akan mengganggu kesehatan terutama bagi pembatik dan lingkungannya. Tujuan penelitian ini adalah untuk mengetahui karakteristik limbah dan dampaknya bagi kesehatan pembatik di Lendah, Kulon Progo. Subjek penelitian ini adalah 76 pembatik di tiga sentra batik, terdiri dari 37 orang dari SB, 20 orang dari FA, dan 19 orang dari SA. Pada responden dilakukan pemeriksaan kesehatan serta wawancara mengenai dampak limbah dan keluhan penyakit yang dialami menggunakan kuesioner. Sampel darah sebanyak $5 \mathrm{ml}$ diambil dan diperiksa kadar hemoglobin ( $\mathrm{Hb})$, packed cell volume (PCV), gula darah, dan kolesterol totalnya. Plasma darah dan air limbah diperiksa kadar $\mathrm{Pb}$ dan Cr-nya dengan metode inductively coupled plasma (ICP); kadar Si-nya dengan atomic absorption spectrofotometry (AAS); dan kadar $\mathrm{Cl}^{-}$-nya dengan spektrofotometri. Gangguan kognitif diperiksa dengan mini-mental state examination (MMSE), sedangkan neuropati perifer diperiksa dengan skor diabetic neuropathy symptom (DNS). Hasil yang diperoleh dianalisis dengan analisis varian dan t-test. Hubungan $\mathrm{Pb}$ dan $\mathrm{Cr}$ dengan gangguan kognitif dianalisis dengan uji korelasi. Kadar kolesterol total dan gula darah dianalisis secara deskriptif. Tidak terdapat perbedaan pengetahuan tentang dampak limbah pada pembatik di tiga sentra batik. Kadar $\mathrm{Pb}, \mathrm{Cr}$, dan $\mathrm{HCl}$ di tiga sentra batik tidak berbeda bermakna $(p>0,05)$, sedangkan kadar Si dalam darah pembatik di tiga sentra berbeda bermakna ( $p<$ $0,05)$. Tidak terdapat hubungan antara kadar $\mathrm{Pb}$ dan $\mathrm{Cr}$ darah dengan gangguan kognitif berdasarkan skor MMSE dan kejadian neuropati perifer berdasarkan skor DNS $(p>0,05)$. Kadar kolesterol normal $(<200 \mathrm{mg} /$ dL) dijumpai pada 70,0-80,5\% pembatik, sedangkan kadar glukosa darah normal ( $<200 \mathrm{mg} / \mathrm{dL}$ ), dijumpai pada $85,0-95,1 \%$ pembatik. Kadar Si darah di tiga sentra batik menunjukkan perbedaan yang bermakna. Keluhan yang banyak dirasakan adalah nyeri sendi dan pusing. Tidak terdapat hubungan antara kadar $\mathrm{Pb}$ dan $\mathrm{Cr}$ darah dengan gangguan kognitif. Kadar kolesterol total pada pembatik cenderung tinggi.

\footnotetext{
*Corresponding author: Suhartini

Departemen IImu Kedokteran Forensik dan Medikolegal, Fakultas Kedokteran, Kesehatan Masyarakat, dan Keperawatan, Universitas Gadjah Mada, Jl. Farmako, Sekip Utara, Yogyakarta 55281, Indonesia

E-mail: suhartini@ugm.ac.id
} 
KATA KUNCI klorida; krom; pembatik; plumbum; silika

ABSTRACT Synthetic batik coloring often uses heavy metals element such as lead (Pb), chromium (Cr), silica (Si), and hydrochloric acid ( $\mathrm{HCl}$ ). The exposure of heavy metals in long period results in health impair on the artisans and eventually harming the environment. The purpose of this research is to analyze the waste characteristics and health impact towards the artisans in the Lendah, Kulon Progo. Seventy-six batik artisan, consisting of 37 from SB, 20 from FA, and 19 from SA underwent $5 \mathrm{ml}$ blood sampling. The samples were used to determine their hemoglobin ( $\mathrm{Hb}$ ) level, packed cell volume (PCV), blood sugar, and total cholesterol. Blood plasma and wastewater were examined for $\mathrm{Pb}$ and $\mathrm{Cr}$ using the inductively coupled plasma (ICP) method; Si using atomic absorption spectrophotometry (AAS); and Cl- using spectrophotometry. Respondents underwent health checks and were interviewed about the impact of waste and disease complaints experienced using a questionnaire. Cognitive disorders were examined using mini-mental state examination (MMSE) and peripheral neuropathy was assessed using diabetic neuropathy symptom (DNS) score. The results obtained were analyzed by analysis of variance and t-test. Correlation test was used to examine the relationship of $\mathrm{Pb}$ and $\mathrm{Cr}$ with cognitive disorders. Total cholesterol levels and blood sugar were analyzed descriptively. There is no difference in knowledge about waste in batik makers in $S B, F A$, and $S A$. The level of $\mathrm{Pb}, \mathrm{Cr}$, and $\mathrm{Cl}^{-}$within the three production centers showed no significant difference $(p>0,05)$, whilst Si level showed significant difference between centers $(p<0,05)$. There is no correlation between $\mathrm{Pb}$ and $\mathrm{Cr}$ blood levels with cognitive impairing according to MMSE and occurence of peripheral neuropathy according to DNS score ( $p>0.05)$. Normal cholesterol levels $(<200 \mathrm{mg} / \mathrm{dL}$ ) and normal blood glucose levels ( $<200 \mathrm{mg} / \mathrm{dL}$ ) were observed in $70.0-80.5 \%$ and $85.0-95.1 \%$ batik artisans, respectively. Si levels in all three production centers' waste shows significant difference. The most frequent complaint was back pain and dizziness. There is no correlation caused by $\mathrm{Pb}$ and $\mathrm{Cr}$ levels toward cognitive impairing. Cholesterol level in batik artisans tended to be high.

KEYWORDS batik artisan; chloride; chromium; lead; silica

\section{Pendahuluan}

Berbagai wilayah di Indonesia telah memiliki banyak usaha mikro kecil menengah (UMKM) batik yang mengembangkan motif batik sesuai dengan kondisi wilayah masing-masing yangdijadikan sebagai identitas daerah, salah satunya adalah di Kabupaten Kulon Progo. Pada tahun 2015 terdapat 108 industri batik di Kulon Progo. ${ }^{1}$ Produk lokal batik semakin terangkat sejak diluncurkannya motif Geblek Renteng sebagai batik identitas Kulon Progo dan program Bela dan Beli Kulon Progo pada tahun 2013. ${ }^{2}$ Lendah merupakan salah satu daerah di Kulon Progo yang memiliki UMKM kerajinan batik yang berkembang pesat.

Pewarnaan batik merupakan salah satu tahapan dalam proses pembuatan batik. Untuk mendapatkan warna yang bagus, lebih terang dan jelas diperlukan timbal ( $\mathrm{Pb})$, krom ( $\mathrm{Cr}$ ), silika (Si) dan ion klorida ( $\left.\mathrm{Cl}^{-}\right)$. Penggunaan bahan pewarna sintetik untuk batik kini meluas karena selain harganya yang terjangkau, juga tersedia pilihan warna yang lebih banyak yang sangat mendukung pengembangan motif dan corak batik. Dampak penggunaan pewarna tersebut adalah meningkatnya paparan pembatik terhadap logam berat seperti $\mathrm{Pb}, \mathrm{Cr}$, Si dan $\mathrm{Cl}^{-}$. Umumnya limbah batik akan langsung dibuang ke sungai melalui drainase air hujan. Industri batik merupakan industri yang berpotensi menghasilkan limbah berbahaya mengandung logam berat yang dapat menyebabkan kerusakan lingkungan dan memberikan dampak negatif pada kesehatan. ${ }^{3,4}$

Gejala toksisitas kronis logam berat sering diabaikan, meskipun pada akhirnya dapat menimbulkan kerusakan berbagai organ. Gangguan neurologi merupakan salah satu efek dari paparan logam berat terutama $\mathrm{Pb}$ dan $\mathrm{Cr}$. Upaya pencegahan untuk meminimalisir efek toksisitas 
dengan menggali pengetahuan pembatik tentang limbah, deteksi dini terdapatnya $\mathrm{Pb}, \mathrm{Cr}, \mathrm{Si}$, dan $\mathrm{Cl}^{-}$ pada populasi berisiko, dan diikuti oleh program berkelanjutan sebagai upaya pencegahan yang utama perlu dilakukan. ${ }^{5,6}$

Paparan dapat terjadi tergantung sifat logam berat. $\mathrm{Si}$ dan $\mathrm{Cl}^{-}$dapat masuk ke dalam tubuh melalui inhalasi, sedangkan $\mathrm{Pb}$ dan $\mathrm{Cr}$ dapat masuk melalui kulit. Setelah terserap, $\mathrm{Pb}$ akan terdistribusi ke jaringan lunak (darah, hati, paruparu, limpa, ginjal, dan sumsum tulang) atau ke tulang. Masa paruh biologis $\mathrm{Pb}$ sekitar 16-40 hari dalam darah dan sekitar 17-27 tahun pada tulang. $\mathrm{Pb}$ diperkirakan bertanggung jawab atas $0,9 \%$ dari total beban penyakit global karena efek paparan $\mathrm{Pb}$. Indikator umum keracunan $\mathrm{Pb}$ anorganik pada manusia adalah kandungan $\mathrm{Pb}$ dalam darah. Kadarnya masih dianggap aman dalam kisaran 0,20,8 ppm. Namun, kadar aman dalam darah manusia sudah sangat dekat dengan batas toksik.,

$\mathrm{Pb}$ sangat memengaruhi sistem saraf pusat. Tanda-tanda keracunan akut $\mathrm{Pb}$ misalnya mudah lelah, mudah mengantuk, lekas marah, sakit kepala, tremor otot, halusinasi, dan kehilangan ingatan. ${ }^{7}$ Ensefalopati terjadi apabila kadar $\mathrm{Pb}$ darah 100 $120 \mathrm{ug} / \mathrm{dL}$ pada orang dewasa dan 80-100 $\mathrm{\mu g} / \mathrm{dL}$ pada anak-anak. ${ }^{8}$

Pemakaian $\mathrm{Cr}$ pada industri logam memberikan kekuatan dan ketahanan terhadap korosi. $\mathrm{Cr}$ juga digunakan pada bahan samak, pigmen cat, dan katalis untuk impregnasi kayu atau fotografi. ${ }^{8,9}$ Logam $\mathrm{Cr}$ trivalen ( $\mathrm{Cr}$ III) merupakan elemen penting dalam nutrisi manusia. $\mathrm{Cr}$ valensi $\mathrm{VI}$ bersifat karsinogenik dan dalam kadar rendah dapat mengiritasi kulit. Paparan kronisnya dapat menyebabkan kerusakan ginjal dan hati, serta dapat merusak jaringan sirkulasi dan saraf. ${ }^{10}$

Si yang terhirup akan mengakibatkan silikosis, bronkitis, atau kanker paru. ${ }^{11}$ Apabila terhirup terus-menerus akan mengganggu dan mengurangi kapasitas paru serta akan menyebabkan iritasi pada paru dan selaput lendir. Kristal Si juga dapat mengiritasi kulit dan mata. ${ }^{12} \mathrm{HCl}$ dengan konsentrasi pekat bisa menimbulkan kabut asam. Si dan $\mathrm{HCl}$ memiliki sifat yang korosif terhadap jaringan tubuh dan berpotensi menimbulkan kerusakan di beberapa organ tubuh seperti mata, kulit, usus, serta organ pernafasan.

Melihat adanya kerentanan pembatik terhadap paparan logam berat yang dapat berdampak pada kesehatan, penelitian ini dilakukan untuk mengetahui karakteristik limbah dan dampaknya terhadap kesehatan pembatik di Lendah Kulon Progo.

\section{Metode}

Desain pada penelitian ini adalah cross-sectional. Penelitian dilakukan di tiga sentra batik di Kecamatan Lendah, Kulon Progo. Populasi pada penelitian ini adalah semua karyawan batik di tiga sentra batik, yaitu SB, FA, dan SA yang bersedia mengikuti penelitian. Teknik pengambilan sampel dilakukan dengan consecutive sampling, yaitu mengambil semua subyek di lokasi tertentu. Seluruh subjek mengisi dan menandatangani informed consent. Pengambilan sampel penelitian disesuaikan dengan kriteria inklusi dan ekslusi yang telah ditetapkan. Kriteria inklusi pada penelitian ini adalah semua pembatik laki-laki maupun perempuan di tiga sentra batik SB, FA dan SA yang bersedia mengikuti penelitian. Kriteria ekslusi pada penelitian ini adalah pembatik yang menyandang diabetes melitus, stroke dan penyakit saraf lainnya.

Untuk mengetahui karakteristik limbah dan dampaknya bagi kesehatan pembatik, dilakukan penggalian pengetahuan pembatik tentang dampak limbah, pemeriksaan kadar $\mathrm{Pb}, \mathrm{Cr}$, $\mathrm{Si}$ dan $\mathrm{Cl}$ dalam darah dan limbah, anamnesis gejala klinis (keluhan yang dirasakan terkait paparan $\mathrm{Pb}, \mathrm{Cr}$, $\mathrm{Si}$ dan $\mathrm{Cl}^{-}$), pemeriksaan gangguan kognitif, serta pemeriksaan kadar gula darah sesaat dan kolesterol total. ${ }^{13}$

Sampel yang diperiksa sebanyak 76 orang pembatik di Kecamatan Lendah, Kulon Progo, yang berasal dari tiga sentra batik, yaitu SB (37 orang), FA (20 orang) dan SA (19 orang). Setelah subjek menandatangani informed consent, darah diambil sebanyak $5 \mathrm{ml}$ dan dilakukan pemeriksaan kadar $\mathrm{Hb}$ (anemia jika pada laki-laki $<13 \mathrm{~g} / \mathrm{dl}$ dan perempuan 
$12 \mathrm{~g} / \mathrm{dl}$ ), ${ }^{13} \mathrm{PCV}$, gula darah sesaat (normal apabila $<200 \mathrm{mg} / \mathrm{dl}$ ), ${ }^{14}$ kolesterol total (normal apabila $<200$ $\mathrm{mg} / \mathrm{dl})^{15}$ di Laboratorium Penelitian dan Pengujian Terpadu Universitas Gadjah Mada (LPPT UGM). Kadar $\mathrm{Pb}$ dan $\mathrm{Cr}$ pada plasma darah dan air limbah diperiksa dengan metode inductively coupled plasma (ICP) di LPPT UGM. Kadar Si diperiksa menggunakan atomic absorption spectroscopy (AAS) dan $\mathrm{Cl}^{-}$menggunakan spektrofotometri di Laboratorium Kimia MIPA UGM.

Subjek diwawancarai menggunakan kuesioner tentang dampak limbah dan gejala penyakit berdasarkan keluhan yang diperkirakan berhubungan dengan toksisitas akibat paparan logam $\mathrm{Pb}, \mathrm{Cr}, \mathrm{Si}$, dan $\mathrm{HCl}$. Gejala penyakit yang dirasakan berupa gejala iritasi mata yakni mata berair, pedih dan gatal; gejalan gangguan nafas yakni sesak nafas; dan gejala gangguan kulit yakni gatal dan kemerahan. Dilakukan juga pemeriksaan antropometrik meliputi berat badan, tinggi badan, dan tekanan darah. Kriteria tekanan darah normal yang dipakai dalam penelitian ini adalah kriteria dari The Eight Joint National Commitee (JNC 8) sesuai usia sebagai berikut: $\geq 60$ tahun sistole < 150 , diastole $<90 ;<60$ tahun sistole $<140$, diastole $<90$; $>18$ tahun dengan chronic kidney disease (CKD) sistole < 140, diastole <90; dan > 18 tahun dengan diabetes sistole $<140$, diastole $<90 .{ }^{16}$

Gangguan kognitif diperiksa dengan minimental state examination (MMSE) yang berisi 5 domain fungsi kognitif yaitu registrasi, orientasi, bahasa, recall, atensi dan kalkulasi. ${ }^{17}$ Kriteria gangguan kognitif yang digunakan sesuai dengan Panduan Penatalaksanaan Demensia Perhimpunan Dokter Spesialis Saraf Indonesia (PERDOSSI). ${ }^{18}$
Subjek dinilai memiliki gangguan kognitif apabila nilai pemeriksaan MMSE kurang dari $27 .{ }^{19}$ Kejadian neuropati perifer diperiksa dengan skor diabetic neuropathy symptom (DNS) ${ }^{20}$ dan diabetic neuropathy examination (DNE). ${ }^{21}$

Normalitas data diuji dengan uji Saphiro-Wilk dan dilakukan transformasi data apabila data tidak normal. Apabila masih tidak normal, data dianalisis menggunakan uji non-parametrik. Hasil yang diperoleh dari ketiga lokasi dibandingkan satu sama lain dengan analisis varian untuk uji parametrik dan Kruskal-Wallis untuk uji non-parametrik dilanjutkan dengan uji post-hoc Tukey untuk uji parametrik dan Mann Whitney untuk uji non-parametrik. Uji korelasi dilakukan untuk melihat hubungan antara kadar $\mathrm{Pb}$ dan $\mathrm{Cr}$ dengan gangguan kognitif. Interval kepercayaan yang dipakai 95\% sehingga nilai $p<$ 0,05 dinyatakan bermakna secara statistik. Hasil pemeriksaan kolesterol total dan gula darah sesaat, dianalisis secara deskripitf. Protokol penelitian ini telah mendapatkan kelaikan etik dari Komisi Etik Fakultas Kedokteran Kesehatan Masyarakat, dan Keperawatan Universitas Gadjah Mada (FK-KMK UGM), dengan nomor KE/FK/0830/EC/2018.

\section{Hasil}

Nilai rata-rata pengetahuan pembatik tentang limbah secara keseluruhan adalah 6,58 dan tidak ada perbedaan bermakna secara statistik di antara tiga sentra batik $(p>0,05)$, namun pengetahuan tentang limbah antara pembatik di SB dan FA menunjukkan perbedaan yang bermakna. Data tampak pada Tabel 1.

Pembatik di SB sebagian besar perempuan

Tabel 1. Nilai pengetahuan tentang limbah pada pembatik di SB, FA, dan SA

\begin{tabular}{lllll}
\hline \multicolumn{1}{c}{ Keterangan } & SB & FA & SA & Nilai $\mathbf{p}$ \\
\hline Mean \pm SD & $7,5 \pm 3,5$ & $5,5 \pm 2,4$ & $6,5 \pm 3,1$ & 0,074 \\
SB - FA & $7,5 \pm 3,5$ & $5,5 \pm 2,4$ & & $0,026^{*}$ \\
SB - SA & $7,5 \pm 3,5$ & & $6,5 \pm 3,1$ & 0,563 \\
FA - SA & & $5,5 \pm 2,4$ & $6,5 \pm 3,1$ & 0,152 \\
\hline
\end{tabular}

SD: standar deviasi; SB, FA, dan SA adalah inisial sentra-sentra batik. Data dinyatakan dalam mean \pm SD. *Bermakna secara statistik $(p<0.05)$. 
Tabel 2. Data karakteristik pembatik dan limbah di SB, FA, dan SA

\begin{tabular}{|c|c|c|c|c|}
\hline Karakteristik & SB & FA & SA & Nilai $\mathbf{P}$ \\
\hline Laki-laki, n (\%) & $12(32,4)$ & $18(90,0)$ & $10(52,6)$ & \\
\hline Perempuan, n (\%) & $25(67,6)$ & $2(10,0)$ & $9(47,4)$ & \\
\hline Total, n (\%) & $37(100,0)$ & $20(100,0)$ & $19(100,0)$ & \\
\hline Umur (th), mean \pm SD & $42,9 \pm 14,4$ & $45,5 \pm 9,3$ & $44,6 \pm 11,7$ & $0,163^{1}$ \\
\hline Berat badan $(\mathrm{kg})$, mean \pm SD & $54,5 \pm 7,4$ & $56,6 \pm 9,0$ & $59,2 \pm 9,5$ & $0,226^{1}$ \\
\hline Tinggi Badan $(\mathrm{cm})$, mean \pm SD & $164,6 \pm 7,8$ & $153,7 \pm 6,2$ & $159,2 \pm 9,0$ & $0,274^{1}$ \\
\hline IMT $\left(\mathrm{kg} / \mathrm{m}^{2}\right)$, mean $\pm \mathrm{SD}$ & $28,3 \pm 3,5$ & $23,9 \pm 3,3$ & $25,9 \pm 2,5$ & $0,155^{1}$ \\
\hline Sistole $(\mathrm{mmHg})$, mean $\pm \mathrm{SD}$ & $122,9 \pm 22,9^{a}$ & $131,2 \pm 15,6^{a}$ & $122,6 \pm 23,3$ & $0,550^{2}$ \\
\hline Diastole $(\mathrm{mmHg})$, mean $\pm \mathrm{SD}$ & $78,1 \pm 13,5$ & $86,7 \pm 9,5$ & $85,3 \pm 9,0$ & $0,211^{1}$ \\
\hline $\mathrm{Hb}(\mathrm{g} / \mathrm{dL})$, mean $\pm \mathrm{SD}$ & $13,3 \pm 2,3^{a}$ & $14,2 \pm 2,9$ & $14,6 \pm 1,8^{\mathrm{a}}$ & $0,078^{1}$ \\
\hline$P C V$, mean $\pm S D$ & $39,4 \pm 6,7$ & $41,1 \pm 7,0$ & $42,1 \pm 4,7$ & $0,398^{1}$ \\
\hline $\mathrm{Pb}$ darah $(\mu \mathrm{g} / \mathrm{dL})$, mean $\pm \mathrm{SD}$ & $77 \pm 40^{\mathrm{a}}$ & $82 \pm 28^{b}$ & $52 \pm 24^{a, b}$ & $0,082^{1}$ \\
\hline $\mathrm{Cr}$ darah $(\mu \mathrm{g} / \mathrm{dL})$, mean $\pm \mathrm{SD}$ & $33 \pm 41^{\mathrm{a}}$ & $33 \pm 19$ & $15 \pm 8^{a}$ & $0,064^{1}$ \\
\hline Si darah (ppm), mean \pm SD & $383,3 \pm 123,9$ & $686,7 \pm 231,3$ & $529,0 \pm 434,6$ & $0,000 *$ \\
\hline $\mathrm{Pb} \operatorname{limbah}(\mu \mathrm{g} / \mathrm{dL})$, mean $\pm \mathrm{SD}$ & $28,1 \pm 17,1$ & $18,1 \pm 14,7$ & $35,8 \pm 14,2$ & $0,338^{1}$ \\
\hline $\mathrm{Cr} \operatorname{limbah}(\mu \mathrm{g} / \mathrm{L})$, mean $\pm \mathrm{SD}$ & $<0,12$ & $<0,12$ & $<0,12$ & $1,000^{1}$ \\
\hline Si limbah (ppm), mean \pm SD & $155,9 \pm 1667,7$ & $194,5 \pm 20,5$ & $225,6 \pm 42,5$ & $0,173^{1}$ \\
\hline Cllimbah (ppm), mean \pm SD & $847,7 \pm 825,7$ & $179,7 \pm 72,9$ & $539,2 \pm 767,6$ & $0,482^{1}$ \\
\hline
\end{tabular}

SD: standar deviasi; IMT: indeks massa tubuh; SB, FA, dan SA adalah inisial sentra-sentra batik. ${ }^{1}$ Uji One-Way ANOVA. ${ }^{2}$ Uji Kruskal-Wallis. *Bermakna secara statistik $(p<0.05)$. Rerata sistol dengan superscript sama tidak berbeda signifikan secara statistik antar keduanya (Mann Whitney $U, p<0.05$ ). ${ }^{a}$ S Supercript yang sama dalam baris yang sama menujukkan perbedaan yang bermakna.

Tabel 3. Gejala-gejala yang dirasakan serta hasil pemeriksaan tekanan darah dan $\mathrm{Hb}$ para pembatik di Lendah, Kulon Progo

\begin{tabular}{|c|c|c|c|c|}
\hline Variabel & $\begin{array}{c}\mathrm{SB}^{* *} \\
\mathrm{n}=37\end{array}$ & $\begin{array}{c}\mathrm{FA} * * \\
\mathrm{n}=20\end{array}$ & $\begin{array}{c}S A^{* *} \\
\mathrm{n}=19\end{array}$ & $\begin{array}{c}\text { Total* } \\
n=76\end{array}$ \\
\hline Gangguan kulit, n (\%) & $10(27)$ & $9(45)$ & $9(47)$ & $28(37)$ \\
\hline Gangguan nafas, n (\%) & $12(32)$ & $1(5)$ & $4(21)$ & $17(22)$ \\
\hline Nyeri sendi, n (\%) & $14(38)$ & $16(80)$ & $7(37)$ & 37 (49) \\
\hline Iritasi pada mata, n (\%) & $5(14)$ & $6(30)$ & $4(21)$ & $15(20)$ \\
\hline Pusing, n (\%) & $13(35)$ & $12(60)$ & $12(63)$ & 37 (49) \\
\hline Hipertensi, n (\%) & $9(24)$ & $10(50)$ & $3(16)$ & $22(29)$ \\
\hline Anemia, n (\%) & $3(8)$ & $4(20)$ & $1(5)$ & $8(11)$ \\
\hline
\end{tabular}

SB, FA, dan SA adalah inisial sentra-sentra batik. *Persentase menunjukkan jumlah subjek yang mengalami gejala dibandingkan dengan total jumlah subjek penelitian. ${ }^{* *}$ Persentase menunjukkan jumlah subjek yang mengalami gejala per lokasi dibandingkan dengan total jumlah subjek yang merasakan gejala. 
Tabel 4. Karakteristik subjek dan hasil pemeriksaan gangguan kognitif dengan MMSE

\begin{tabular}{ll}
\hline Karakteristik & $\mathbf{n}(\%)$ \\
\hline $\begin{array}{l}\text { Jenis Kelamin } \\
\text { Laki-laki }\end{array}$ & $10(14)$ \\
Perempuan & $32(76)$ \\
Usia & \\
$\quad 17-54$ tahun & $38(90)$ \\
$>55$ tahun & $4(10)$ \\
Skor MMSE & \\
$27-30$ (normal) & $7(17)$ \\
$21-26$ (mild) & $28(66)$ \\
$11-20$ (moderate) & $7(17)$ \\
$0-10$ (severe) & $0(0)$ \\
\hline MMSE: Mini-mental state examination
\end{tabular}

(67,6\%), sedangkan di FA mayoritas laki-laki $(90,0 \%)$. Hasil pemeriksaan antropometrik, tekanan darah, kadar $\mathrm{Hb}, \mathrm{Pb}, \mathrm{Cr}, \mathrm{Si}$, dan $\mathrm{Cl}^{-}$darah serta limbah dari ketiga sentra batik di Lendah, Kulon Progo, ditunjukkan dalam Tabel 2.

Secara statistik data antropometrik pembatik di tiga sentra batik tidak menunjukkan perbedaan bermakna, demikian juga kadar $\mathrm{Pb}, \mathrm{Cr}, \mathrm{Si}$, dan $\mathrm{Cl}^{-}$ pada limbah dan darah, namun kadar Si pada darah menunjukkan perbedaan yang bermakna. Kadar $\mathrm{Hb}$ antara pembatik di SB dan SA, menunjukkan perbedaan yang bermakna, demikian juga kadar $\mathrm{Pb}$ darah antara pembatik di SB dan SA, dan antara pembatik di FA dan SA. Kadar $\mathrm{Cr}$ darah antara pembatik di SB dan SA secara statistik juga menunjukkan perbedaan yang bermakna.

Gejala yang dirasakan oleh pembatik di Lendah, mayoritas nyeri sendi dan pusing $(49 \%$ dari total pembatik). Pembatik FA paling sering merasakan gejala nyeri sendi (80\%), sedangkan pusing paling banyak dikeluhkan (63\%) oleh pembatik SA. Padapemeriksaan tekanan darah, 10 dari 20 (50\%) pekerja yang diperiksa di sentra FA mengalami hipertensi (sistole $\geq 140 \mathrm{mmHg}$ atau diastole $\geq 90 \mathrm{mmHg}$ ) dan $20 \%$ pembatik memiliki kadar $\mathrm{Hb}$ rendah ( $\leq 12 \mathrm{mg} / \mathrm{dL}$ ). Gejala-gejala yang dirasakan pembatik serta hasil pemeriksaan darah dan $\mathrm{Hb}$ disajikan dalam Tabel 3.

Hanya 42 orang dari jumlah total 76 orang dapat diperiksa dengan MMSE karena pemeriksaan
MMSE tidak bisa dilakukan pada responden dengan pendidikan formal $<3$ tahun dan yang tidak kooperatif. Analisis regresi logistik menunjukkan tidak terdapat korelasi antara kadar $\mathrm{Pb}$ darah dan kejadian gangguan $\operatorname{kognitif}(p=0,058 ; \mathrm{Cl} 95 \%)$. Kadar $\mathrm{Cr}$ dalam darah juga tidak berkorelasi dengan kejadian gangguan kognitif ( $p=0,079 ; \mathrm{Cl} 95 \%$ ). Karakteristik subjek yang diperiksa gangguan kognitifnya disajikan pada Tabel 4.

Dari 42 subjek tersebut, sistem skoring DNS mendiagnosis neuropati perifer pada 19 subjek (45\%) sedangkan sistem skoring DNE mendiagnosis kelainan tersebut pada 2 subjek (5\%). Analisis regresi logistik menunjukkan tidak terdapat korelasi antara kadar $\mathrm{Pb}$ darah dan kejadian neuropati perifer berdasarkan sistem skoring DNS ( $p=0,964$; $\mathrm{Cl} 95 \%)$ maupun sistem skoring DNE ( $p=0,116 ; \mathrm{Cl}$ 95\%). Analisis regresi logistik juga menunjukkan tidak terdapat korelasi antara kadar $\mathrm{Cr}$ darah dan kejadian neuropati perifer berdasarkan sistem skoring DNS ( $p=0,283 ; \mathrm{Cl} 95 \%)$ maupun sistem skoring DNE ( $p=0,180 ; \mathrm{Cl} 95 \%)$.

Sebagian besar pembatik mempunyai kadar kolesterol total dan gula darah sesaat dalam batas normal, namun secara keseluruhan kadar kolesterol yang tinggi lebih banyak dijumpai pada pembatik, dibanding kadar gula darah yang tinggi. Hasil pemeriksaan gula darah sesaat dan kolesterol total di tiga sentra batik di Lendah, Kulon Progo ditunjukkan dalam Tabel 5.

\section{Pembahasan}

Nilai rata-rata pengetahuan tentang dampak limbah pada pekerja batik relatif rendah. Hal ini disebabkan karena sebagian besar responden adalah pembatik yang kadang membatik di rumah masing-masing (tidak di pabrik) serta tidak berperan dalam proses pengolahan batik, baik pewarnaan, penguncian warna, pelorotan, pengecapan, maupun pencucian. Pengetahuan yang rendah mengenai dampak limbah menandakan belum mengertinya pekerja batik terhadap bahaya toksisitas limbah batik terhadap kesehatan. Hal ini perlu diperhatikan karena masih dijumpai pembatik yang tidak 
Tabel 5. Frekuensi subjek dengan kadar gula darah dan kolesterol total yang normal dan tidak normal di SB, FA dan SA

\begin{tabular}{lcccccc}
\hline \multirow{2}{*}{ Variabel } & \multicolumn{2}{c}{ SB } & \multicolumn{2}{c}{ FA } & \multicolumn{2}{c}{ SA } \\
\cline { 2 - 7 } & $\begin{array}{c}\text { Normal } \\
\mathbf{n}(\%)\end{array}$ & $\begin{array}{c}\text { Tidak } \\
\text { Normal } \\
\mathbf{n}(\%)\end{array}$ & $\begin{array}{c}\text { Normal } \\
\mathbf{n}(\%)\end{array}$ & $\begin{array}{c}\text { Tidak } \\
\text { Normal } \\
\mathbf{n}(\%)\end{array}$ & $\begin{array}{c}\text { Normal } \\
\mathbf{n}(\%)\end{array}$ & $\begin{array}{c}\text { Tidak } \\
\text { Normal } \\
\mathbf{n}(\%)\end{array}$ \\
\hline Gula darah sesaat & $39(95)$ & $3(5)$ & $18(90)$ & $2(10)$ & $17(85)$ & $3(15)$ \\
Kolesterol total & $33(80)$ & $8(20)$ & $14(70)$ & $6(30)$ & $13(70)$ & $6(30)$ \\
\hline
\end{tabular}

Gula darah sesaat, normal ( $\leq 200 \mathrm{mg} / \mathrm{dl})$, tidak normal (>200mg/dl); kolesterol total, normal $(\leq 200 \mathrm{mg} / \mathrm{dl})$, tidak normal (>200 mg/dl)

menggunakan alat pelindung diri secara optimal sehingga membahayakan kesehatan diri. Perlu dilakukan sosialisasi penggunaan alat pelindung diri dan kaitannya dengan dampak kesehatan.

Pada penelitian ini, skoring MMSE dilakukan secara keseluruhan gangguan tiap domain. Hasil skoring MMSE tidak dihubungkan dengan usia pada penelitian ini. Hasil penelitian ini menunjukkan tidak ada korelasi antara kadar $\mathrm{Pb}$ darah dan kejadian gangguan kognitif berdasarkan skor MMSE. Hal ini berbeda dengan studi yang dilakukan oleh Harbani yang menemukan adanya korelasi antara kadar $\mathrm{Pb}$ darah dengan gangguan kognitif pada domain bahasa, registrasi, dan visuospasial. ${ }^{22}$

Hasil penelitian ini juga menunjukkan tidak ada korelasi antara kadar $\mathrm{Cr}$ dalam darah dengan kejadian gangguan kognitif. Studi khusus mengenai kadar $\mathrm{Cr}$ yang dihubungan dengan gangguan kognitif masih belum banyak dilakukan. Studi yang dilakukan oleh Green et al. menemukan hubungan antara tingginya kadar $\mathrm{Cr}$ dalam darah pada pasien dengan metal-on-metal hip implant di Inggris tahun 2003 - 2011 dengan gangguan neuropsikiatri yang di nilai dengan back depression inventory (BDI) dan MMSE. ${ }^{23}$

Hasil penelitian ini menunjukkan tidak terdapat korelasi antara kadar $\mathrm{Pb}$ darah dan kejadian neuropati perifer berdasarkan sistem skoring DNS maupun sistem skoring DNE. Hal ini berbeda dengan studi yang dilakukan oleh Mochammad et al. yang menemukan korelasi positif berkekuatan sedang antara kadar $\mathrm{Pb}$ darah dan neuropati perifer yang diukur dengan kriteria modified total neuropathy score (mTNS) pada petugas stasiun pengisian bahan bakar untuk umum (SPBU). ${ }^{19}$ Penelitian tersebut melaporkan sebanyak 5 (9\%) dari total 55 subjek memiliki kadar $\mathrm{Pb}$ darah yang tinggi, yaitu di atas $25 \mu \mathrm{g} / \mathrm{dl} .{ }^{19}$ Kandungan $\mathrm{Pb}$ darah yang tinggi juga ditemukan pada penelitian oleh Shobha et al. yang mendapati semua subjeknya mengalami wrist drop dan finger drop tanpa disertai gejala sensorik pada kadar timbal antara 37,8-107,8 $\mathrm{\mu g} /$ dl. ${ }^{24}$ Temuan tersebut tidak didapatkan dalam penelitian ini. Kadar tertinggi $\mathrm{Pb}$ darah pada subjek yang memenuhi kriteria inklusi dan eksklusi ialah $1,68 \mu \mathrm{g} / \mathrm{dl}$ sehingga masih dalam batas aman yang direkomendasikan oleh Center for Disease Control and Prevention (CDC), yaitu di bawah $10 \mu \mathrm{g} / \mathrm{dl}^{25}$

Hasil penelitian ini juga menunjukkan tidak terdapat korelasi antara kadar $\mathrm{Cr}$ darah dan kejadian neuropati perifer berdasarkan sistem skoring DNS maupun sistem skoring DNE. Studi mengenai pengaruh paparan kromium terhadap sistem saraf pada manusia belum banyak dilakukan. Penelitian oleh Kitamura et al. menunjukkan skor olfactory recognition tresholds pada pekerja pabrik terpapar $\mathrm{Cr}$ lebih tinggi secara bermaknsa dibandingkan kontrol serta berkorelasi positif dengan lama paparan. Konsentrasi $\mathrm{Cr}$ di udara pada penelitian tersebut bervariasi antara 0,005-0,03 $\mathrm{mg} / \mathrm{m}^{3}$ untuk kromium(VI) dan antara 0,005-0,06 mg/ $\mathrm{m}^{3}$ untuk kromium(III). ${ }^{26}$ Penelitian pada hewan coba juga belum menemukan batas yang jelas untuk menentukan kadar $\mathrm{Cr}$ darah yang berpotensi memberikan efek toksik terhadap sistem saraf. 
Penelitian oleh Kim et al. tidak mendapati adanya lesi pada otak tikus CDF jantan dan betina yang terpapar $30 \mathrm{mg} / \mathrm{m}^{3}$ kromium (III) dalam bentuk kromium oksida atau kromium sulfat biasa selama tiga bulan. ${ }^{27}$ Studi serupa oleh Derelanko et al. juga tidak menemukan lesi otak pada tikus SpragueDawley jantan yang terpapar $1,15 \mathrm{mg} / \mathrm{m}^{3} \mathrm{Cr}(\mathrm{VI})$ dalam bentuk kromium trioksida selama tiga bulan. ${ }^{28}$

Ketika penyerahan hasil laboratorium kadar gula darah sesaat dan kolesterol total pada pembatik, subjek diberi informasi untuk tetap menjaga kesehatan dan pola makan serta anjuran pemeriksaan lebih lanjut bagi pembatik yang nilai gula darah dan kolesterolnya melebihi batas normal. Kelemahan penelitian ini adalah gejala yang ditemukan merupakan gejala yang dirasakan pada saat pemeriksaan sehingga tidak bisa menghubungkan langsung toksisitas logam berat dengan gejala, serta jumlah sampel yang sedikit.

\section{Kesimpulan}

Kadar $\mathrm{Pb}, \mathrm{Cr}$, dan $\mathrm{HCl}$ pada limbah dan darah pembatik di tiga sentra batik tidak menunjukkan perbedaan bermakna, sedangkan kadar Si pada darah menunjukkan perbedaan yang bermakna. Keluhan yang banyak dirasakan adalah nyeri sendi dan pusing. Tidak terdapat hubungan antara kadar $\mathrm{Pb}$ dan $\mathrm{Cr}$ darah dengan gangguan kognitif. Kadar kolesterol pada pembatik cenderung tinggi.

\section{Ucapan terima kasih}

Kami mengucapkan terima kasih kepada Fakultas Kedokteran, Kesehatan Masyarakat, dan Keperawatan, Universitas Gadjah Mada yang sudah memberikan dana melalui Hibah Dana Masyarakat untuk Pengabdian Masyarakat tahun 2018.

\section{Konflik kepentingan}

Penelit menyatakan tidak ada konflik kepentingan di antara peneliti dan pemberi dana penelitian.

\section{Daftar pustaka}

1. Pahlevy N, Sudiarso A. Analisis kelayakan batik cap pewarna campuran (Alami-sintesis) (Studi kasus di Batik Yoga, Gulurejo, Lendah, Kulon Progo) [Thesis]. Yogyakarta; Universitas Gadjah Mada; 2016.

2. Susilo EG, Rijanta R. Kajian implementasi "Belabeli Kulon Progo"(Kasus: Air-ku, Batik Geblek Renteng, dan Tomira). Jurnal Bumi Indonesia. 2017;6(3).

3. Riwayati I, Hartati I, Purwanto H, Kimia ST. Adsorpsi logam berat timbal dan kadmium pada limbah batik menggunakan biosorben pulpa kopi terxanthasi. InProdising Seminar Nasional Aplikasi Sains \& Teknologi (SNAST) 20142014 (pp. 1-8).

4. Sasongko DP, Tresna WP. Identifikasi unsur dan kadar logam berat pada limbah pewarna batik dengan metode analisis pengaktifan neutron. Jurnal Ilmu Pengetahuan dan Teknologi TELAAH. 2010;27:22-7.

5. Mason LH, Harp JP, Han DY. Pb neurotoxicity: neuropsychological effects of lead toxicity. BioMed research international. 2014;2014.

6. Chen P, Miah MR, Aschner M. Metals and neurodegeneration. F1000Research. 2016;5.

7. Velickova N, Kamcev N. Genotoxicological effects of heavy metals on humans cells. American Journal of Environmental Protection. 2014;2(4):71-3.

8. Naja GM, Volesky B. Toxicity and sources of $\mathrm{Pb}, \mathrm{Cd}, \mathrm{Hg}, \mathrm{Cr}, \mathrm{As}$, and radionuclides in the environment. Heavy metals in the environment. 2009 Jun 23;8.

9. Burk RF, Prasad AS, Oberleas D. Trace elements in human health and disease. Vol. II, Academic Press, New York. 1976:105.

10. Rao DL. Heavy metals causing toxicity in humans, animals and environment. JCHPS. 2014;3:172-4.

11. Ilmiawati C, Reza M, Russilawati R. Edukasi pencegahan penyakit paru akibat paparan debu silika pada pengrajin batu akik di Kota Padang. LOGISTA-Jurnal Ilmiah Pengabdian kepada Masyarakat. 2017 Jun 30;1(1):1-0.

12. Yuarsa TA. Pengaruh debu vulkanik pada erupsi gunung berapi DIY terhadap kesehatan paru. 
Jurnalis: Jurnal Lingkungan dan Sipil. 2019 Mar 15;2(1):51-64.

13. Hastuti $P$, Sunarti $S$, Prasetyastuti $P$, Ngadikun N, Tasmini T, Rubi DS, Sutarni S, Harahap IK, Dananjoyo K, Suhartini S, Pidada IB. Hubungan timbal dan krom pada pemakaian pewarna batik dengan kadar hemoglobin dan packed cell volume pada pengrajin batik di Kecamatan Lendah Kulon Progo. Journal of Community Empowerment for Health.2018;1(1):28-35.

14. American Diabetes Association. 2. Classification and diagnosis of diabetes: standards of medical care in diabetes-2018. Diabetes care. 2018 Jan 1;41(Supplement 1):S13-27.

15. Grundy SM, Stone NJ. Cholesterol clinical practice Guidelines AHA/ACC/AACVPR/AAPA/ ABC/ACPM/ADA/AGS/APhA/ASPC/NLA/ $P C N A$ guideline on the management of blood cholesterol: a report of the American College of Cardiology/American heart association task force on clinical practice guidelines. Circulation. 2018(Nov).

16. Hernandez-Vila E. A review of the JNC 8 blood pressure guideline. Texas Heart Institute Journal. 2015 Jun;42(3):226-8.

17. Harahap HS, Rianawati SB. The profile of cognitive function of patients HIV/AIDS In Dr. Saiful Anwar Malang Hospital. Malang Neurology Journal. 2015 Jan 1;1(1):1-6.

18. Ong PA, Rambe AS, Widjojo FS, Laksmidewi AA. Panduan Praktik klinik diagnosis dan penatalaksanaan demensia. Jakarta: Perhimpunan Dokter Spesialis Saraf Indonesia. 2015.

19. Mochammad I, Sutarni S, Dahlan P. Korelasi antara kadar timbal dalam darah dengan neuropati perifer pada petugas stasiun pengisian bahan bakar untuk umum [Doctoral dissertation]. Yogyakarta; Universitas Gadjah Mada;2012.

20. Meijer, J.W.G., Smit, A.J., Sonderen, E.V., Groothoff, J.W., Eisma, W.H. and Links, T.P., 2002. Symptom scoring systems to diagnose distal polyneuropathy in diabetes: the Diabetic Neuropathy Symptom score. Diabetic
Medicine, 19(11), pp.962-965.

21. Meijer JW, van Sonderen E, Blaauwwiekel EE, Smit AJ, Groothoff JW, Eisma -WH, Links TP. Diabetic neuropathy examination: a hierarchical scoring system to diagnose distal polyneuropathy in diabetes. Diabetes Care. 2000 Jun 1;23(6):750-3.

22. Harbani N, Sutarni S, Wibowo S. Korelasi antara kadar plumbum dalam darah dengan neuropati perifer pada petugas stasiun pengisian bahan bakar umum Kotamadya Yogyakarta [Doctoral dissertation]. Yogyakarta; Universitas Gadjah Mada; 2012.

23. Green B, Griffiths E, Almond S. Neuropsychiatric symptoms following metal-on-metal implant failure with cobalt and chromium toxicity. BMC psychiatry. 2017 Dec;17(1):33.

24. Shobha N, Taly AB, Sinha S, Venkatesh T. Radial neuropathy due to occupational lead exposure: Phenotypic and electrophysiological characteristics of five patients. Annals of Indian Academy of Neurology. 2009 Apr;12(2):111.

25. Center for Disease Control and Prevention. Very high blood lead levels among adults United States, 2002-2011 [Internet]. Cdc.gov; 2018 [diakses pada 22 Oktober 2018]. Tersedia di: https://www.cdc.gov/mmwr/preview/ mmwrhtml/mm6247a6.ht

26. Kitamura F, Yokoyama K, Araki S, Nishikitani M, Choi JW, Yum YT, Park HC, Park SH, Sato $\mathrm{H}$. Increase of olfactory threshold in plating factory workers exposed to chromium in Korea. Industrial health. 2003;41(3):279-85.

27. Kim HY, Lee SB, Jang BS. Subchronic inhalation toxicity of soluble hexavalent chromium trioxide in rats. Archives of toxicology. 2004 Jul $1 ; 78(7): 363-8$.

28. Derelanko MJ, Rinehart WE, Hilaski RJ, Thompson RB, Löser E. Thirteen-week subchronic rat inhalation toxicity study with a recovery phase of trivalent chromium compounds, chromic oxide, and basic chromium sulfate. Toxicological sciences: an official journal of the Society of Toxicology. 1999 Dec 1;52(2):278-88. 